\title{
Aplikasi Asesmen Calon Debitur menggunakan Naive Bayes di Koperasi Mitra Sejahtera SMK Negeri 1 Kota Sukabumi
}

\author{
Indra Griha Tofik Isa \\ Jurusan Manajemen Informatika \\ Politeknik Negeri Sriwijaya \\ Palembang, Indonesia \\ indra_isa_mi@polsri.ac.id
}

\begin{abstract}
Cooperatives have an important role in economic development in Indonesia. One of them is the Mitra Sejahtera Cooperative (KMS), which is located in Sukabumi - West Java. The problem that in KMS was the increase in bad credit during the 2015-2019 period which had an impact on decreasing cash circulation flow and income of the KMS. So that in this study focuses on making a prospective debtor assessment application by implementing the Naive Bayes algorithm to provide recommendations on the feasibility of prospective debtors who have the potential for bad credit or not. The training data used are 862 data with parameters of age, gender, loan amount, occupation, income and repayment period. The stages taken include: (1) Research Initiation, (2) Data Selection, (3) Data Pre Processing, (4) System Design, (5) System Implementation, and (6) Program Testing. In system design using structured design, while the implementation of the system uses Microsoft Visual Studio 2012 tools and MySQL database. The test results from the prospective debtor assessment application obtained an accuracy rate of $86 \%$.
\end{abstract}

Keywords-Cooperative Aplication, Naive Bayes, Decision Support System

Abstrak- Koperasi memiliki peranan penting dalam pembangunan perekonomian di Indonesia. Salah satunya adalah Koperasi Mitra Sejahtera (KMS) yang berlokasi di Kota Sukabumi - Jawa Barat. Permasalahan yang muncul dalam KMS adalah terjadinya peningkatan kredit macet selama periode 2015-2019 yang berdampak pada menurunnya arus sirkulasi kas maupun pendapatan pihak KMS. Sehingga dalam penelitian ini berfokus dalam pembuatan aplikasi asesmen calon debitur dengan mengimplementasikan algoritma Naive Bayes guna memberikan rekomendasi kelayakan calon debitur yang memiliki potensi kredit macet atau tidak. Data training yang digunakan sebanyak 862 data dengan parameter usia, jenis kelamin, jumlah pinjaman, pekerjaan, penghasilan dan jangka waktu pengembalian. Tahapan yang dilakukan meliputi (1) Inisiasi Penelitian, (2) Data Selection, (3) Data Pre Processing, (4) Perancangan Sistem, (5) Implementasi Sistem, (6) Pengujian Program. Dalam perancangan sistem menggunakan perancangan terstruktur, sedangkan implementasi sistem menggunakan tools Microsoft Visual Studio 2012 dan basis data MySQL. Hasil pengujian dari aplikasi asesmen calon debitur didapatkan nilai tingkat akurasi sebesar $86 \%$.
Kata Kunci- Aplikasi Koperasi, Naive Bayes, Sistem Pendukung Keputusan

\section{PENDAHULUAN}

Koperasi menjadi bagian yang tidak terpisahkan dan merupakan representasi gotong royong bangsa Indonesia. Pada dasarnya koperasi berlandaskan tolong menolong dan gotong royong yang didorong oleh keinginan menolong orang lain guna memperbaiki penghidupan ekonomi [1]. Saat ini koperasi di bawah Kementerian Koperasi dan Usaha Kecil dan Menengah (KemenkopUKM) dan tersebar sebanyak 45.489 unit dengan jumlah keanggotaan sebanyak 22.463.738 anggota di seluruh Indonesia hingga akhir tahun 2019 [2]. Jika dihitung rerata dari tahun ke tahun terjadi peningkatan jumlah koperasi di Indonesia, seperti dari tahun 2011 hingga 2015 terjadi peningkatan koperasi aktif sebanyak 4139 unit [3]. Adapun di Jawa Barat jumlah koperasi tergolong tinggi yakni sebanyak 13.247 koperasi dengan jumlah keanggotaan sebanyak 2.040.509 [2]. Salah satu koperasi di Jawa Barat yaitu Koperasi Mitra Sejahtera (KMS) yang berada di Kota Sukabumi didirikan bertujuan untuk kesejahteraan guru-guru di lingkungan SMK Negeri 1 Kota Sukabumi. KMS merupakan perpaduan antara koperasi konsumsi dan koperasi simpan pinjam. Saat ini KMS memiliki jumlah keanggotaan sebanyak 484 dan total aset senilai Rp 1.854.350.000 hingga akhir tahun 2019. Dari segi modal usaha, KMS memiliki tren kecenderungan naik selama 5 tahun terakhir dari 2015 hingga 2019 sebesar Rp 1.434.000.000, seperti yang ditunjukkan pada Gambar 1.

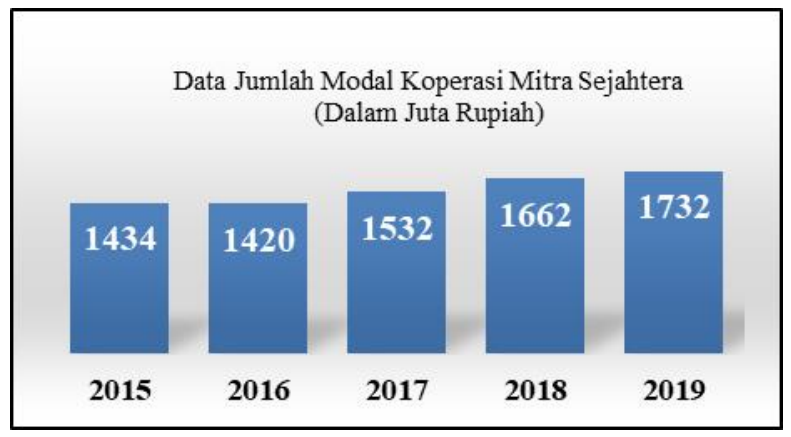

Gambar 1. Data Jumlah Modal Koperasi Mitra Sejahtera periode 2015 - 2019 
Dalam menjalankan kegiatan operasionalnya yang terdiri dari penjualan dan pembelian barang konsumsi, simpan pinjam serta pengolahan data anggota koperasi di KMS sudah dilakukan secara terkomputerisasi sejak tahun 2012 dengan berbasis desktop. Selama perjalanan operasional KMS, khususnya dalam proses peminjaman anggota, rata-rata setap tahun sekitar 7 - 10\% terjadi kredit macet yang berdampak pada menurunnya arus sirkulasi kas maupun pendapatan pihak KMS. Jika hal ini terus berulang dan persentasi kredit macet cenderung naik, maka akan menimbulkan potensi tersendatnya arus kas KMS dan bahkan koperasi mengalami pailit sehingga KMS tidak mampu lagi mensejahterakan anggotanya. Beberapa penyebab dari sering terjadinya kredit macet salah satunya adalah dalam proses asesmen awal data debitur tidak dilakukan secara mendalam dengan melihat aspek kriteria calon debitur maupun histori dari data kredit macet yang telah terjadi sebelumnya.

Dalam penelitian ini guna meminimalisir peningkatan kredit macet adalah dengan mengimplementasikan metode Naive Bayes dalam aplikasi asesmen calon debitur. Naive Bayes merupakan salah satu teknik klasifikasi dalam pencarian kesimpulan dengan menggunakan probabilitas [4]. Banyaknya jumlah laporan data kredit di KMS selama ini hanya dijadikan sebagai laporan tahunan dan belum dijadikan sebagai pengetahuan yang dapat digunakan untuk rekomendasi dalam pengambilan keputusan. Sehingga dalam penelitian ini laporan tersebut akan dijadikan dasar dalam memberikan rekomendasi asesmen calon debitur. Adapun parameter yang dilibatkan dalam asesmen calon debitur meliputi usia, pekerjaan, jumlah pinjaman, jenis kelamin, penghasilan, jangka waktu pengembalian dan status pembayaran dengan data training sebanyak 862 data dari rentang waktu tahun 2015 hingga tahun 2019. Dalam mengimplementasikan Naive Bayes pada aplikasi juga memperhatikan aspek fungsional pengguna, untuk memudahkan pengguna dalam mengoperasikan aplikasi tersebut [5].

Beberapa penelitian lainnya terkait implementasi naive bayes adalah dalam peminatan siswa di SMAN 5 Pamekasan, dimana dilakukan proses klasifikasi data dengan parameter penilaian ujian siswa. Data training sebanyak 720 record data dengan pengambilan data 5 kali jumlah data testing. Hasil akhir dari penelitian ini menghasilkan nilai akurasi sebesar 92,11\% dan rate error sebesar 7,02\% [6]. Penelitian berikutnya pada Koperasi KSPPS BMT dilakukan untuk kelayakan calon anggota kredit dengan data training sebanyak 472 data. Hasil akhir dari penelitian ini berupa produk aplikasi dengan hasil pengujian berupa nilai precision $82 \%$, accuracy $80 \%$ dan recall $94 \%$ [7].

Sedangkan dalam penelitian A. P. Fadilah mengimplementasikan Naive Bayes dalam pemilihan konsentrasi mata kuliah di Universitas Komputer Indonesia yang terdiri dari konsentrasi Rekayasa Sistem Informasi dan Teknologi Informasi. Pemilihan dilakukan berdasarkan penilaian mata kuliah yang terdiri dari Lab Pemrograman I, Lab Pemrograman II, Lab Pemrograman III, Pemrograman Web, Jaringan Komputer, Konsep Sistem Informasi, Analisis Proses Bisnis, Konsep E-Business dan Manajemen Sistem
Informasi. Data training yang digunakan sebanyak 375 data dengan tingkat akurasi sebesar $81 \%$ [8]. Berdasarkan latar belakang tersebut dalam penelitian ini berfokus dalam pembuatan Aplikasi Asesmen Calon Debitur di Koperasi KMS, sehingga memberikan kemudahan bagi pihak koperasi dalam mengasesmen debitur yang memiliki potensi kredit macet.

\section{TINJAUAN PUSTAKA}

\section{A. Knowledge Discovery of Database (KDD)}

Knowledge Discvoery of Database (KDD) merupakan proses eksplorasi dan pemodelan dari repositori data yang besar. Proses KDD terorganisir dan sistematis untuk mengidentifikasi pattern yang valid, berguna, baru dan mudah dipahami dari sekumpulan data yang kompleks [9]. Proses KDD juga bersifat berulang dan interaktif, serta terdapat data mining yang merupakan bagian tidak terpisahkan di dalamnya. Terdapat 9 tahapan dalam KDD yang dimulai dari penentuan goal apa yang ingin dicapai dari proses KDD hingga diakhiri oleh implementasi dari KDD. Gambar 2 menunjukkan 9 tahapan dalam KDD.

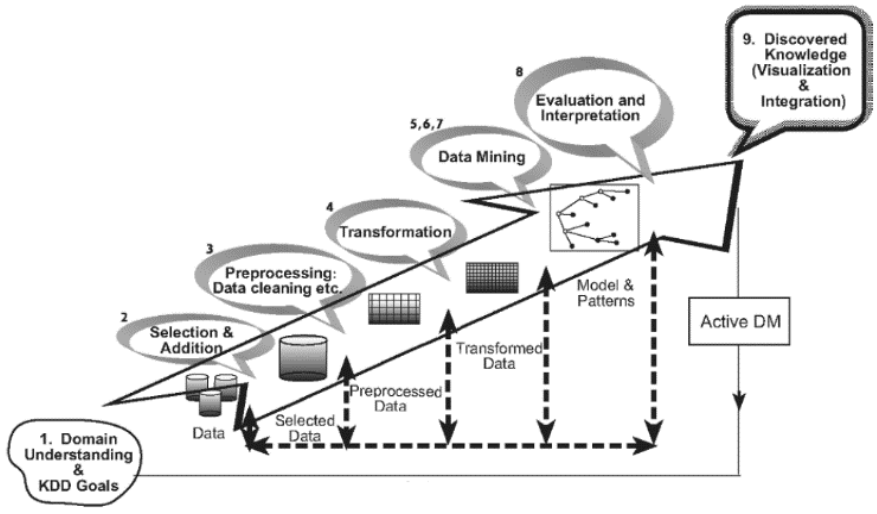

Gambar 2. 9 Tahapan Proses Knowledge Discovery of Database

Dari Gambar 2 dapat dilihat bahwa 9 tahapan proses KDD terdiri dari :

1) Penyamaan persepsi dan penentuan tujuan dari proses KDD;

2) Pemilihan data yang akan digunakan dalam proses KDD

3) Data Preprocessing yang bertujuan untuk menghilangkan data error, seperti redudansi data, missing value, proses normalisasi data

4) Data Transformation yakni konversi menjadi variabel dummy yang memudahkan dalam mengekstrak data menjadi pengetahuan

5) Pemilihan model data mining yang digunakan, misal ddklastering, klasifikasi, atau regresi

6) Penerapan teknik data mining secara teknis dan detail, misal dalam klasifikasi terdapat beberapa teknik seperti neural network, decision trees, naive bayes. Sehingga dalam implementasi KDD dipilih mana yang lebih relevan antara data yang diteliti dan goal yang dihasilkan. 
7) Proses Data Mining yakni penambangan data berdasarkan algoritma data mining yang ditentukan pada poin 6 .

8) Evaluasi dan interpretasi data dengan menguji akurasi dari data yang dihasilkan, misalnya pengujian melalui penambahan data baru.

9) Penggunaan hasil KDD sebagai rekomendasi dalam pengambilan keputusan atau kebijakan.

\section{B. Data Mining}

Terminologi data mining umumnya diasosiasikan dengan KDD, namun pada faktanya data mining merupakan bagian utama dalam proses KDD. Secara definisi, data mining merupakan proses untuk menemukan sebuah pattern dari sejumlah data yang besar dan kompleks. Sumber data yang digunakan dapat berasal dari basis data, data warehouse, website, repositori informasi lainnya, atau data yang diinput dalam sistem secara dinamis [10]

Sebuah pattern menjadi baik jika melalui test data yang valid dengan tingkat kepastian data, novelty, dan memiliki potensi berdayaguna (misalnya data tersebut dapat ditindaklanjuti atau divalidasi bagi user yang melakukan data prediksi) dan mudah dipahami. Pattern yang baik merepresentasikan pengetahuan. Data mining dapat dilakukan pada berbagai tipe data selama datanya bermakna bagi target yang ditetapkan, seperti data dalam basis data, data warehouse, data transaksi dan tipe data tingkat lanjut, termasuk di dalamnya sequence data, data streams, spatial dan spatiotemporal data, data teks dan multimedia, data graf dan jaringan, data web [10].

\section{Classification}

Permasalahan dari data klasifikasi adalah banyaknya ragam variasi dari implementasi data mining dalam aplikasi. Hal ini dikarenakan permasalahan dalam mempelajari hubungan minat antara feature variables dan target variable [11]. Klasifikasi merupakan salah satu bagian dalam metode data mining untuk menemukan fungsi dan model yang membedakan kelas sebuah objek yang tidak diketahui labelnya. Dalam memenuhi tujuan tersebut, pengklasifikasian membentuk sebuah model yang dapat membedakan seperangkat data ke dalam class berbeda berdasarkan fungsi dan aturan tertentu. Ada beragam model dalam klasifikasi, diantaranya pohon keputusan, formula secara matematis maupun aturan "Jika-Maka" [12].

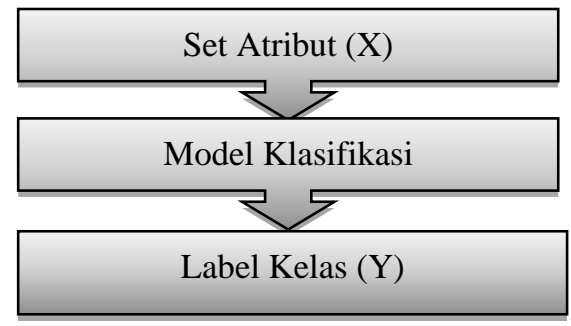

Gambar 3. Diagram Model Klasifikasi

\section{Naive Bayes}

Naive Bayes merupakan salah satu bagian dari teknik klasifikasi dimana menggunakan metode statistik dan probabilitas dalam perhitungannya [13]. Naive Bayes pertama kali dikembangkan oleh ilmuwan Inggris, yakni Thomas Bayes yang pada awal mulanya dipergunakan untuk memprediksi kemungkinan di masa depan berdasarkan histori pengalaman sebelumnya. Klasifikasi Naive Bayes diasumsikan bahwa tidak ada hubungannya antara ciri kelas tertentu dengan kelas lainnya, meskipun kelas tersebut memiliki ciri atau tidak [14]. Berikut ini merupakan persamaan dari Naive Bayes:

$$
P(H \mid X)=\frac{P(H \mid X) \cdot P(H)}{P(X)}
$$

Keterangan:

\begin{tabular}{|c|c|}
\hline $\mathrm{X}$ & Data dengan class yang belum diketahui \\
\hline $\mathrm{H}$ & $\begin{array}{l}\text { Hipotesis data } \mathrm{X} \text { dimana merupakar } \\
\text { sebuah class } \text { spesifik }\end{array}$ \\
\hline $\mathrm{P}(\mathrm{H} \mid \mathrm{X})$ & $\begin{array}{l}\text { Probabilitas hipotesis } \mathrm{H} \text { berdasarkan } \\
\text { kondisi X }\end{array}$ \\
\hline $\mathrm{P}(\mathrm{H})$ & Probabilitas Hipotesis $\mathrm{H}$ \\
\hline $\mathrm{P}(\mathrm{X} \mid \mathrm{H})$ & $\begin{array}{l}\text { Probabilitas } \mathrm{X} \text { berdasarkan kondisi pa } \\
\text { hipotesis } \mathrm{H}\end{array}$ \\
\hline (X) & Probabilitas X \\
\hline
\end{tabular}

\section{METODE PENELITIAN}

Terdapat 7 tahapan dalam metode penelitian, seperti pada gambar 4 berikut:

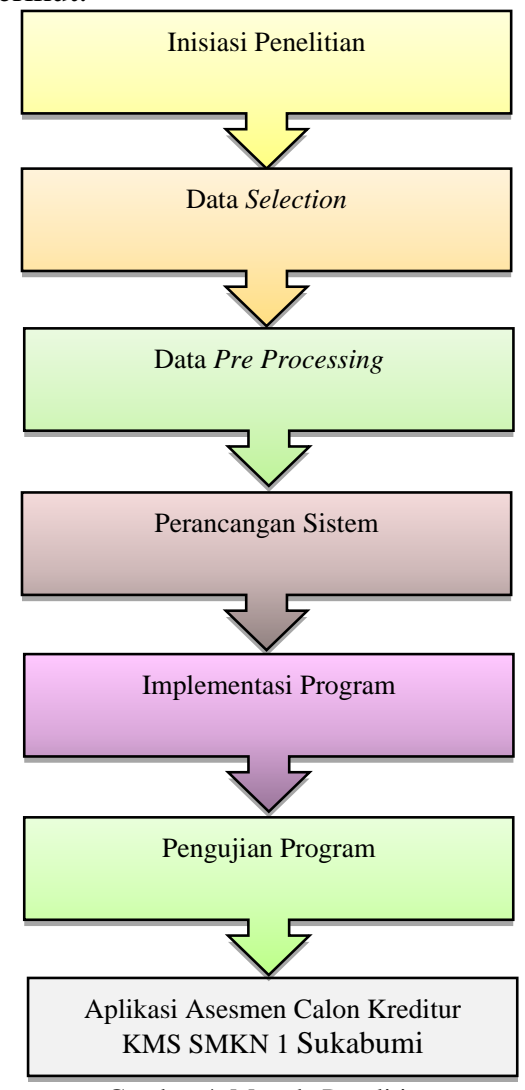

Gambar 4. Metode Penelitian 


\section{A. Inisiasi Penelitian}

Tahapan ini merupakan kegiatan awal dalam penelitian yang dilakukan. Dalam tahapan ini ditentukan jumlah data yang digunakan sebagai data training berupa laporan kredit dari periode 2015 - 2019 dengan jumlah sebanyak 862 data. Perancangan dalam pengembangan sistem dengan menggunakan terstruktur dan implementasi menggunakan aplikasi berbasis desktop. Secara detail spesifikasi kebutuhan perangkat lunak dan perangkat keras terdapat pada Tabel 1.

TABLE I. SPESIFIKASI PERANGKAT LUNAK DAN PERANGKAT KERAS

\begin{tabular}{|c|l|l|}
\hline No & \multicolumn{1}{|c|}{ Deskripsi } & \multicolumn{1}{|c|}{ Spesifikasi Minimum } \\
\hline 1 & Sistem Operasi & Windows 7 / + \\
\hline 2 & Basis Data & MySQL \\
\hline 3 & IDE Pengembangan Sistem & Microsoft Visual Studio 2012 \\
\hline 4 & Prosesor & Intel Pentium i3 / setara \\
\hline 5 & RAM & 4 GB \\
\hline 6 & HDD & $200 \mathrm{~GB}$ \\
\hline
\end{tabular}

\section{B. Data Selection}

Setelah ditentukan data yang akan dijadikan landasan dalam penelitian, selanjutnya adalah memilah data secara teknis parameter apa saja yang akan digunakan. Secara keseluruhan dari laporan kredit terdapat 20 parameter namun dalam penelitian ini hanya menggunakan 7 parameter yang terdiri dari usia, pekerjaan, jumlah pinjaman, jenis kelamin, penghasilan, jangka waktu pengembalian dan status pembayaran. Hal ini dikarenakan parameter tersebut yang sering digunakan oleh analis kredit Koperasi KMS untuk melihat data debitur yang memiliki kredit macet. Tabel 2 menunjukkan parameter dalam laporan kredit (warna kuning menunjukkan parameter yang digunakan dalam penelitian).

TABLE II. PARAMETER LAPORAN KREDIT

\begin{tabular}{|c|c|c|}
\hline No & Parameter & Keterangan \\
\hline 1 & No Akun & No Akun dari debitur / nasabah \\
\hline 2 & Nama Nasabah & Nama lengkap dari debitur / nasabah \\
\hline 3 & Alamat & $\begin{array}{l}\text { Alamat tinggal dan korespondensi dari } \\
\text { debitur }\end{array}$ \\
\hline 4 & Tempat Lahir & Tempat Lahir dari debitur / nasabah \\
\hline 5 & Tanggal Lahir & Tanggal Lahir dari debitur / nasabah \\
\hline 6 & Usia & $\begin{array}{l}\text { Selisih antara Tanggal Today dengan } \\
\text { Tanggal Lahir dari debitur / nasabah }\end{array}$ \\
\hline 7 & Jenis Kelamin & Jenis Kelamin dari debitur / nasabah \\
\hline 8 & Jumlah Pinjaman & $\begin{array}{l}\text { Berapa jumlah pinjaman yang dipinjam } \\
\text { oleh debitur / nasabah }\end{array}$ \\
\hline 9 & Pekerjaan & Pekerjaan dari debitur / nasabah \\
\hline 10 & Jumlah Bunga & $\begin{array}{l}\text { Bunga yang dibebankan ke debitur / } \\
\text { nasabah berdasarkan jumlah pinjaman }\end{array}$ \\
\hline 11 & Total Pinjaman & $\begin{array}{l}\text { Penjumlahan jumlah pinjaman dan } \\
\text { jumlah bunga }\end{array}$ \\
\hline 12 & Denda & $\begin{array}{l}\text { Besaran jumlah keterlambatan dikali } \\
\text { dengan variabel bunga }\end{array}$ \\
\hline 13 & $\begin{array}{l}\text { Jumlah } \\
\text { Keterlambatan }\end{array}$ & $\begin{array}{l}\text { Jumlah hari keterlambatan pembayaran } \\
\text { dari jatuh tempo }\end{array}$ \\
\hline 14 & $\begin{array}{l}\text { Tanggal Jatuh } \\
\text { Tempo }\end{array}$ & $\begin{array}{l}\text { Tenggat waktu debitur / nasabah dalam } \\
\text { melakukan pembayaran }\end{array}$ \\
\hline 15 & Penghasilan & Penghasilan dari debitur / nasabah \\
\hline 16 & $\begin{array}{l}\text { Jangka Waktu } \\
\text { Pengembalian } \\
\end{array}$ & Jumlah bulan pengembalian pinjaman \\
\hline 17 & Status Pelunasan & Status pelunasan pinjaman, yang terdiri \\
\hline
\end{tabular}

\begin{tabular}{|c|l|l|}
\hline No & \multicolumn{1}{|c|}{ Parameter } & \multicolumn{1}{c|}{ Keterangan } \\
\hline & & dari LUNAS dan TIDAK LUNAS \\
\hline 18 & $\begin{array}{l}\text { Tanggal } \\
\text { Keanggotaan }\end{array}$ & $\begin{array}{l}\text { Tanggal debitur / nasabah mendaftar } \\
\text { sebagai anggota koperasi }\end{array}$ \\
\hline 19 & Status Pernikahan & Status pernikahan dari debitur / nasabah \\
\hline 20 & Nama Ahli Waris & Ahli waris dari debitur / nasabah \\
\hline
\end{tabular}

\section{Data Pre Processing}

Dalam tahapan ini dilakukan perapihan data / data cleaning sesuai dengan 7 parameter yang merupakan reduksi dari 20 parameter laporan kredit KMS. Menghilangkan data-data redudansi dan pemberian nilai variabel dari masing-masing parameter tersebut. Data yang sudah valid selanjutnya menjadi data training, yang nantinya menjadi dasar dalam pengambilan rekomendasi kesimpulan dalam penginputan data baru atau data testing. Tabel 3 menunjukkan data spesifik dari parameter yang digunakan.

TABLE III. DATA SPESIFIK 7 PARAMETER LAPORAN KREDIT

\begin{tabular}{|c|l|l|}
\hline No & \multicolumn{1}{|c|}{ Parameter } & \multicolumn{1}{|c|}{ Data Spesifik } \\
\hline 1 & Usia & $\begin{array}{l}20-35 \text { tahun } \\
36-55 \text { tahun }\end{array}$ \\
\hline 2 & Jenis Kelamin & $\begin{array}{l}\text { Laki-laki } \\
\text { Perempuan }\end{array}$ \\
\hline 3 & Jumlah Pinjaman & $\begin{array}{l}5000.000 \mathrm{~s} / \mathrm{d} 10.000 .000 \\
10.000 .000 \mathrm{~s} / \mathrm{d} 20.000 .000\end{array}$ \\
\hline 4 & Pekerjaan & $\begin{array}{l}\text { PNS } \\
\text { NON-PNS }\end{array}$ \\
\hline 5 & Penghasilan & $\begin{array}{l}\text { Kurang dari 4.000.000 } \\
\text { Lebih dan sama dengan 4.000.000 }\end{array}$ \\
\hline 6 & $\begin{array}{l}\text { Jangka Waktu } \\
\text { Pengembalian }\end{array}$ & $\begin{array}{l}12 \text { Bulan } \\
24 \text { Bulan }\end{array}$ \\
\hline 7 & Status Pelunasan & LUNAS TIDAK LUNAS \\
\hline
\end{tabular}

\section{Perancangan Sistem}

Perancangan sistem dengan menggunakan perancangan terstruktur. Diagram yang dibuat dalam perancangan sistem meliputi diagram konteks, diagram alir data dan entity relationship diagram. Selain itu dalam perancangan sistem juga dibuat perancangan basis data dan perancangan tampilan antarmuka pengguna.

\section{E. Implementasi Program}

Setelah dilakukan perancangan sistem, tahapan berikutnya adalah implementasi dari perancangan sistem tersebut ke dalam bahasa pemrograman. Tools dan bahasa pemrograman yang digunakan dalam penelitian ini adalah Microsoft Visual Studio 2012 dengan bahasa pemrograman visual basic, sedangkan basis data menggunakan MySQL.

\section{F. Pengujian Program}

Pengujian program dilakukan setelah implementasi program, dimana pengujian program dilakukan dengan menggunakan 2 teknik pengujian, yakni (1) blackbox testing yang menguji program dari segi fungsional. Pada pengujian ini dibuat skenario pengujian untuk menguji bagian sistem input proses - output; (2) Pengujian data training, dimana dalam pengujian ini menguji tingkat akurasi dari data training yang 
ada dalam aplikasi yang dibuat. Pengujian dilakukan dengan penginputan data record, dan membandingkan hasil pengujian dengan data sebenarnya, sehingga didapatkan berapa persen (\%) tingkat error / data fail yang didapatkan dari data uji tersebut. Pihak yang dilibatkan dalam pengujian ini terdiri dari ketua koperasi, bagian keuangan koperasi dan beberapa pengurus dari Koperasi Mitra Sejahtera.

\section{HASIL DAN PEMBAHASAN}

\section{A. Data Selection}

Data yang diseleksi berdasarkan laporan kredit Koperasi Mitra Sejahtera yang dipilih secara acak selama periode 2015 - 2019. Secara keseluruhan data yang diambil berjumlah 862 data kredit. Seperti yang telah diuraikan sebelumnya, bahwa dalam laporan kredit terdapat 20 parameter namun dalam penelitian ini data yang diambil hanya terdiri dari 7 parameter. Gambar 5 menunjukkan bentuk data mentah berupa laporan kredit nasabah Koperasi Mitra Sejahtera.

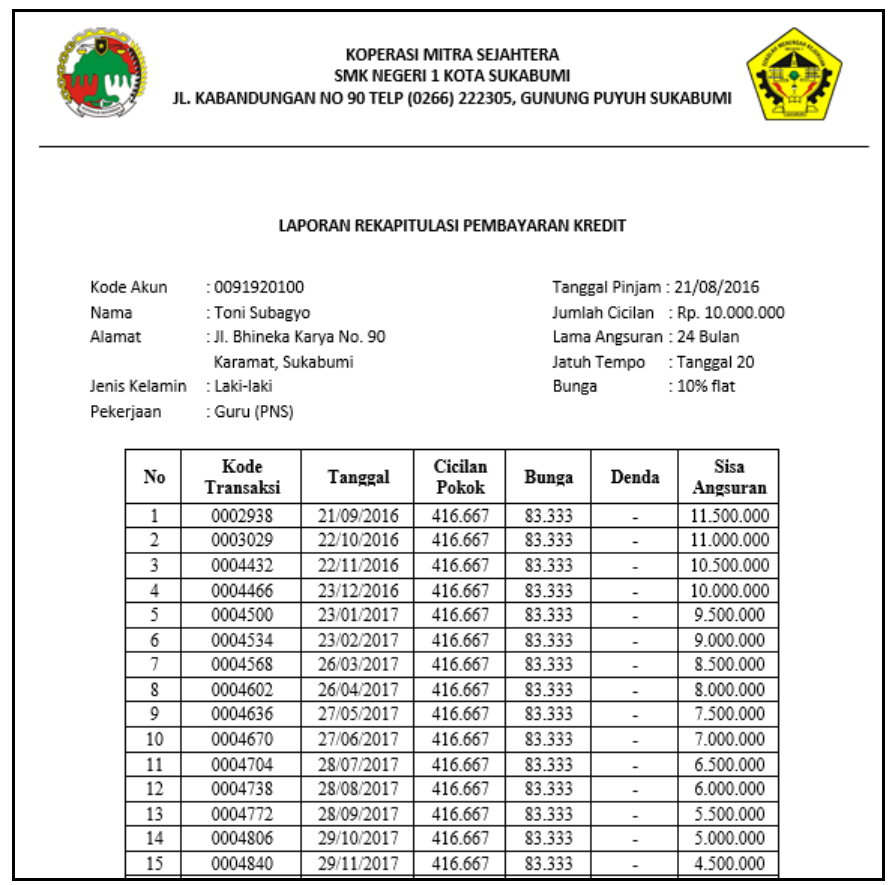

Gambar 5. Laporan Kredit Nasabah Koperasi Mitra Sejahtera

7 Parameter yang terdiri dari Usia, Jenis Kelamin, Jumlah Pinjaman, Pekerjaan, Penghasilan, Jangka Waktu Pengembalian dan Status Pelunasan direkap ke dalam tabel data mentah 7 parameter dengan total data sebanyak 862 record data, seperti pada Tabel 4.

TABLE IV. DATA MENTAH 7 PARAMETER

\begin{tabular}{|c|c|c|c|c|c|c|}
\hline No & Usia & $\begin{array}{c}\text { Jenis } \\
\text { Kelamin }\end{array}$ & $\begin{array}{c}\text { Jml } \\
\text { Pinjaman }\end{array}$ & Pekerjaan & $\cdots$ & $\begin{array}{c}\text { Status } \\
\text { Lunas }\end{array}$ \\
\hline 1 & 25 & Laki-laki & 10 & $\begin{array}{c}\text { Guru } \\
\text { Tetap }\end{array}$ & & Lunas \\
\hline 2 & 43 & Laki-laki & 5 & PNS & & Lunas \\
\hline 3 & 37 & Laki-laki & 5 & Prudential & & Lunas \\
\hline
\end{tabular}

\begin{tabular}{|c|c|c|c|c|c|c|}
\hline No & Usia & $\begin{array}{c}\text { Jenis } \\
\text { Kelamin }\end{array}$ & $\begin{array}{c}\text { Jml } \\
\text { Pinjaman }\end{array}$ & Pekerjaan & $\ldots$ & $\begin{array}{c}\text { Status } \\
\text { Lunas }\end{array}$ \\
\hline 4 & 44 & Perempuan & 15 & Swasta & & Lunas \\
\hline 5 & 42 & Laki-laki & 10 & $\begin{array}{c}\text { Bank } \\
\text { Mega }\end{array}$ & & Lunas \\
\hline 6 & 27 & Perempuan & 10 & Guru & & T.Lunas \\
\hline 7 & 36 & Perempuan & 10 & Staf TU & & T.Lunas \\
\hline 8 & 28 & Perempuan & 12.5 & Bank BRI & & Lunas \\
\hline 9 & 52 & Laki-laki & 5 & Honor & & T.Lunas \\
\hline 10 & 33 & Laki-laki & 12.5 & Honor & & Lunas \\
\hline 11 & 42 & Perempuan & 12.5 & Staf TU & & Lunas \\
\hline$\ldots$ & $\ldots$ & $\ldots$ & $\ldots$ & $\ldots$ & $\ldots$ & $\ldots$ \\
\hline 862 & 49 & Perempuan & 10 & PNS & & T.Lunas \\
\hline
\end{tabular}

\section{B. Data Pre Processing}

Dalam memudahkan pembacaan dan interpretasi data training, maka dilakukan proses data preprocessing dimana dilakukan cleaning data dengan menghilangkan data-data redudansi (data duplikat), data dengan nilai kosong (missing values), serta pengkategorian baik parameter (Class) maupun data record didalamnya. Pengkategorian class menggunakan data seperti pada Tabel 5 .

TABLE V. DATA CLASS

\begin{tabular}{|c|c|l|}
\hline No & Nama Class & \multicolumn{1}{c|}{ Parameter } \\
\hline 1 & C1 & Usia \\
\hline 2 & C2 & Jenis Kelamin \\
\hline 3 & C3 & Jumlah Pinjaman \\
\hline 4 & C4 & Pekerjaan \\
\hline 5 & C5 & Penghasilan \\
\hline 6 & C6 & Jangka Waktu Pengembalian \\
\hline 7 & C7 & Status Pelunasan \\
\hline
\end{tabular}

Untuk class Pekerjaan (C4) terdiri dari berbagai varian pekerjaan, yakni PNS, karyawan BUMN, karyawan swasta, wirausaha, dan pekerja harian lepas. Sehingga dalam memudahkan pembobotan nilai, dibuat kedalam 2 kategori utama yakni PNS (P) dan NON-PNS (NP). Secara keseluruhan, deskripsi kategori class yang digunakan terdapat dalam Tabel 6.

TABLE VI. DESKRIPSI KATEGORI CLASS

\begin{tabular}{|c|c|c|c|}
\hline No & Parameter & \multicolumn{2}{|c|}{ Deskripsi Kategori Class } \\
\hline \multirow{2}{*}{1} & \multirow{2}{*}{ Usia } & $\mathrm{U} 1$ & $20-35$ tahun \\
\hline & & $\mathrm{U} 2$ & $36-55$ tahun \\
\hline \multirow{2}{*}{2} & \multirow{2}{*}{ Jenis Kelamin } & $\mathrm{L}$ & Laki-laki \\
\hline & & $\mathrm{P}$ & Perempuan \\
\hline \multirow{2}{*}{3} & \multirow{2}{*}{ Jumlah Pinjaman } & JP1 & $5000.000 \mathrm{~s} / \mathrm{d} 10.000 .000$ \\
\hline & & JP2 & $10.000 .000 \mathrm{~s} / \mathrm{d} 20.000 .000$ \\
\hline \multirow{2}{*}{4} & \multirow{2}{*}{ Pekerjaan } & $\mathrm{P}$ & PNS \\
\hline & & NP & NON-PNS \\
\hline \multirow{2}{*}{5} & \multirow{2}{*}{ Penghasilan } & $\mathrm{P} 1$ & $<5.000 .000$ \\
\hline & & $\mathrm{P} 2$ & $>=5.000 .000$ \\
\hline \multirow{2}{*}{6} & \multirow{2}{*}{$\begin{array}{l}\text { Jangka Waktu } \\
\text { Pengembalian }\end{array}$} & W1 & 12 Bulan \\
\hline & & $\mathrm{W} 2$ & 24 Bulan \\
\hline \multirow{2}{*}{7} & \multirow{2}{*}{ Status Pelunasan } & $\mathrm{L}$ & LUNAS \\
\hline & & $\mathrm{TL}$ & TIDAK LUNAS \\
\hline
\end{tabular}

Pada class Status Pelunasan (C7), dari 862 data didapatkan $8.7 \%$ data atau 75 record data dengan nilai Status Pelunasan $=$ TIDAK LUNAS (TL). Sedangkan sisanya yakni 93.2\% atau 
787 record data didapatkan nilai Status Pelunasan $=$ LUNAS (L). Berikut tabel 7 menunjukkan data record yang sudah disesuaikan dengan kategori class.

TABLE VII. DATA RECORD KATEGORI CLASS

\begin{tabular}{|c|c|c|c|c|c|c|c|}
\hline No & C1 & C2 & C3 & C4 & C5 & C6 & C7 \\
\hline 1 & 25 & L & 10 & P & 4.2 & 24 & L \\
\hline 2 & 43 & L & 5 & P & 4.2 & 12 & L \\
\hline 3 & 37 & L & 5 & NP & 2.5 & 12 & L \\
\hline 4 & 44 & P & 15 & NP & 3 & 24 & L \\
\hline 5 & 42 & L & 10 & NP & 4 & 24 & L \\
\hline 6 & 27 & P & 10 & P & 4.0 & 12 & TL \\
\hline 7 & 36 & P & 10 & P & 4.2 & 12 & TL \\
\hline 8 & 28 & P & 12.5 & NP & 3.85 & 12 & L \\
\hline 9 & 52 & L & 5 & NP & 2 & 12 & TL \\
\hline 10 & 33 & L & 12.5 & NP & 2 & 12 & L \\
\hline 11 & 42 & P & 12.5 & P & 3.6 & 12 & L \\
\hline$\ldots$ & $\ldots$ & $\ldots$ & $\ldots$ & $\ldots$ & $\ldots$ & $\ldots$ & $\ldots$ \\
\hline 862 & 862 & P & 10 & P & 3.6 & 12 & TL \\
\hline
\end{tabular}

C. Implementasi Naive Bayes dalam Aplikasi Asesmen Debitur Koperasi Mitra Sejahtera

Dalam mengimplementasikan Naive Bayes, dilakukan perhitungan probabilitas dari masing-masing $\mathrm{C} 1$ hingga $\mathrm{C6}$ terhadap probabilitas C7 (Status Pelunasan). Langkah pertama adalah membuat probabilitas $\mathbf{L}$ dan $\mathbf{T L}$ dari C7:

$$
\begin{aligned}
& \mathbf{P}(\mathbf{C} 7) \\
& \mathrm{P}(\mathrm{C} 7=\text { "L" }) \quad=787 / 862=0,91 \\
& \mathrm{P}(\mathrm{C} 7=\text { "TL" })=75 / 862=0,087
\end{aligned}
$$

Berikutnya adalah menghitung probabilitas $\mathrm{C} 1$ hingga C6 terhadap $\mathrm{C} 7$, yang selanjutnya disebut dengan $\mathbf{X}$. Misalnya terdapat data testing dengan data: (1) Usia = 25 tahun; (2) Jenis Kelamin = Perempuan; (3) Jumlah Pinjaman $=\mathrm{Rp}$ 8.000.000; (4) Pekerjaan = Karyawan Swasta; (5) Penghasilan = Rp 3.600.000 dan (6) Jangka Waktu Pengembalian = 12 Bulan.

Dari data testing tersebut, berdasarkan tabel 6 dapat dibuat class kriteria sebagai berikut:
1. Usia $=25$
$\rightarrow \mathrm{C} 1=\mathrm{U} 1$
2. Jenis Kelamin $=$ Perempuan
$\rightarrow \mathrm{C} 2=\mathrm{P}$
3. Jumlah Pinjaman $=\operatorname{Rp} 8.000 .000$
$\rightarrow \mathrm{C} 3=\mathrm{JP} 1$
4. Pekerjaan = Karyawan Swasta
$\rightarrow \mathrm{C} 4=\mathrm{NP}$
$\rightarrow \mathrm{C} 5=\mathrm{P} 1$
5. Penghasilan $=\operatorname{Rp} 3.600 .000$
6. Jangka Pengembalian $=12$ Bulan $\rightarrow \mathrm{C} 6=\mathrm{W} 1$

Selanjutnya adalah menghitung berapa jumlah data dari masing-masing kriteria C1 hingga C6 terhadap C7, misal berdasarkan 862 data training didapatkan kriteria $\mathrm{C} 1=\mathrm{U} 1$ dengan status kriteria $\mathrm{C} 7=\mathrm{L}$ sejumlah 524 data, sedangkan kriteria $\mathrm{C} 1=\mathrm{U} 1$ dengan status kriteria $\mathrm{C} 7=\mathrm{TL}$ sejumlah 27 data. Berikutnya adalah menghitung jumlah kriteria $\mathrm{C} 2=\mathrm{P}$ dengan status kriteria $\mathrm{C} 7=\mathrm{L}$ didapatkan data sejumlah 326 data dan kriteria $\mathrm{C} 2=\mathrm{P}$ dengan status kriteria $\mathrm{C} 7=\mathrm{TL}$ sejumlah 40 data. Langkah yang sama dilakukan untuk menghitung C3 hingga C6.

Setelah dilakukan perhitungan jumlah data dari masingmasing kriteria, selanjutnya dihitung probabilitasnya dengan formulasi $\mathbf{P}(\mathbf{X} \mid \mathbf{C} 7)$ sebagai berikut:

\section{$\mathbf{P}(\mathbf{X} \mid \mathbf{C} 7)$}

$$
\begin{aligned}
& \mathrm{P}(\mathrm{C} 1=\mathrm{U} 1 \mid \mathrm{C} 7=\mathrm{L}) \\
& \mathrm{P}(\mathrm{C} 1=\mathrm{U} 1 \mid \mathrm{C} 7=\mathrm{TL}) \\
& \mathrm{P}(\mathrm{C} 2=\mathrm{P} \mid \mathrm{C} 7=\mathrm{L}) \\
& \mathrm{P}(\mathrm{C} 2=\mathrm{P} \mid \mathrm{C} 7=\mathrm{TL}) \\
& \mathrm{P}(\mathrm{C} 3=\mathrm{JP} 1 \mid \mathrm{C} 7=\mathrm{L}) \\
& \mathrm{P}(\mathrm{C} 3=\mathrm{JP} 1 \mid \mathrm{C} 7=\mathrm{TL}) \\
& \mathrm{P}(\mathrm{C} 4=\mathrm{NP} \mid \mathrm{C} 7=\mathrm{L}) \\
& \mathrm{P}(\mathrm{C} 4=\mathrm{NP} \mid \mathrm{C} 7=\mathrm{TL}) \\
& \mathrm{P}(\mathrm{C} 5=\mathrm{P} 1 \mid \mathrm{C} 7=\mathrm{L}) \\
& \mathrm{P}(\mathrm{C} 5=\mathrm{P} 1 \mid \mathrm{C} 7=\mathrm{TL}) \\
& \mathrm{P}(\mathrm{C} 1=\mathrm{W} 1 \mid \mathrm{C} 7=\mathrm{L}) \\
& \mathrm{P}(\mathrm{C} 1=\mathrm{W} 1 \mid \mathrm{C} 7=\mathrm{TL})
\end{aligned}
$$$$
\begin{array}{ll}
=524 / 787 & =0.66 \\
=27 / 75 & =0.36 \\
=326 / 787 & =0.41 \\
=40 / 75 & =0.53 \\
=486 / 787 & =0.61 \\
=33 / 75 & =0.44 \\
=441 / 787 & =0.56 \\
=49 / 75 & =0.65 \\
=201 / 787 & =0.25 \\
=28 / 75 & =0.37 \\
=574 / 787 & =0.73 \\
=35 / 75 & =0.46
\end{array}
$$

Selanjutnya adalah mengalikan antara $\mathrm{P}(\mathrm{X} \mid \mathrm{C} 7)$ dengan $\mathrm{P}(\mathrm{C} 7)$, baik yang bernilai $\mathbf{L}$ maupun $\mathbf{T L}$, sehingga dihasilkan perhitungan sebagai berikut:

$$
\begin{aligned}
& \text { Hasil hitung data testing dengan nilai } \mathrm{C} 7=\mathbf{L} \\
& \mathrm{P}(\mathrm{X} \mid \mathrm{C} 7=\mathrm{L}) \times \mathrm{P}(\mathrm{C} 7=\mathrm{L})= \\
& (0.66 \times 0.41 \times 0.61 \times 0.56 \times 0.25 \times 0.73) \times(0,91)=\mathbf{0 . 0 1 5 3}
\end{aligned}
$$

Hasil hitung data testing dengan nilai $\mathrm{C} 7=\mathbf{T L}$

$\mathrm{P}(\mathrm{X} \mid \mathrm{C} 7=\mathrm{TL}) \times \mathrm{P}(\mathrm{C} 7=\mathrm{TL})=$

$(0.36 \times 0.53 \times 0.44 \times 0.65 \times 0.37 \times 0.46) \times(0,087)=$ 0.0008

Hasil dari perhitungan tersebut didapatkan bahwa nilai terbesar dari $\mathrm{P}(\mathrm{X} \mid \mathrm{C} 7) \times \mathrm{P}(\mathrm{C} 7)$ adalah $\mathbf{0 . 0 1 5 3}$ yang artinya bahwa data testing tersebut menghasilkan nilai $\mathbf{C 7} \mathbf{L}$ ("LUNAS") atau dengan kata lain nilai C7 = L memiliki nilai yang lebih besar dibandingkan dengan C7 = TL. Sehingga data testing dengan nilai kriteria $\mathrm{C} 1=\mathrm{U} 1, \mathrm{C} 2=\mathrm{P}, \mathrm{C} 3=\mathrm{JP} 1$, $\mathrm{C} 4=\mathrm{NP}, \mathrm{C} 5=\mathrm{P} 1$ dan $\mathrm{C} 6=\mathrm{W} 1$ memiliki nilai probabilitas LUNAS yang lebih besar dibandingkan dengan nilai probabilitas TIDAK LUNAS.

\section{Perancangan Sistem}

Dalam perancangan sistem menggunakan pendekatan terstruktur dengan membuat diagram konteks. Gambar 6 menunjukkan Diagram Konteks dalam Aplikasi Asesmen Debitur Koperasi Mitra Sejahtera dengan terdiri dari 1 entitas, yakni Admin sebagai operator pengguna system.

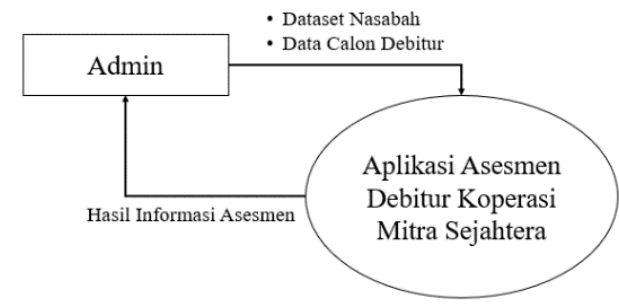

Gambar 6. Diagram Konteks Aplikasi Asesmen Debitur Koperasi Mitra Sejahtera

Proses secara terperinci digambarkan dalam Data Flow Diagram (DFD) pada Gambar 7, yang terdiri dari Input 
Dataset Nasabah, Asesmen Calon Debitur dan Cetak Hasil Asesmen serta 2 data store yakni dataset debitur dan hasil asesmen.

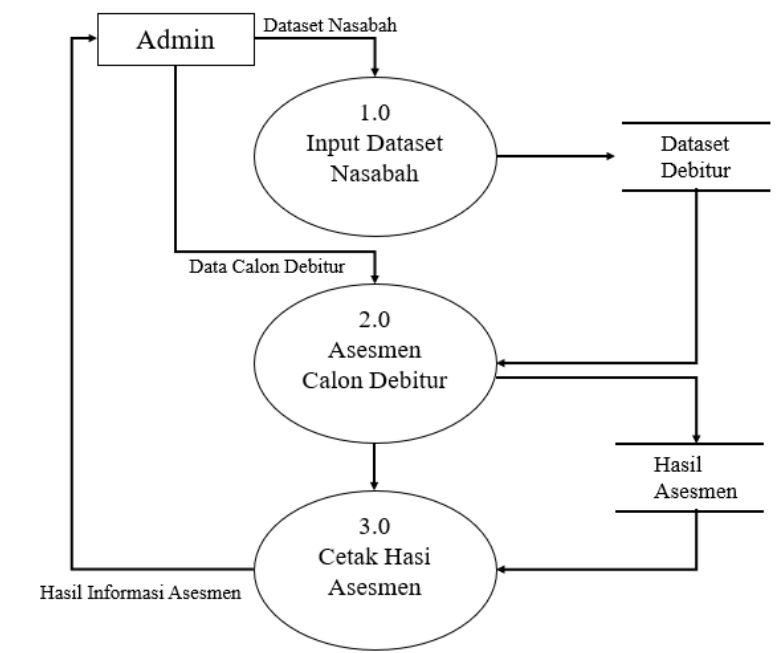

Gambar 7. Data Flow Diagram Aplikasi Asesmen Debitur Koperasi Mitra Sejahtera

Untuk mengetahui keterhubungan antar entitas maupun data store dan sebagai landasan dalam perancangan basis data, maka dibuat entity relationship diagram (ERD) pada Gambar 8.

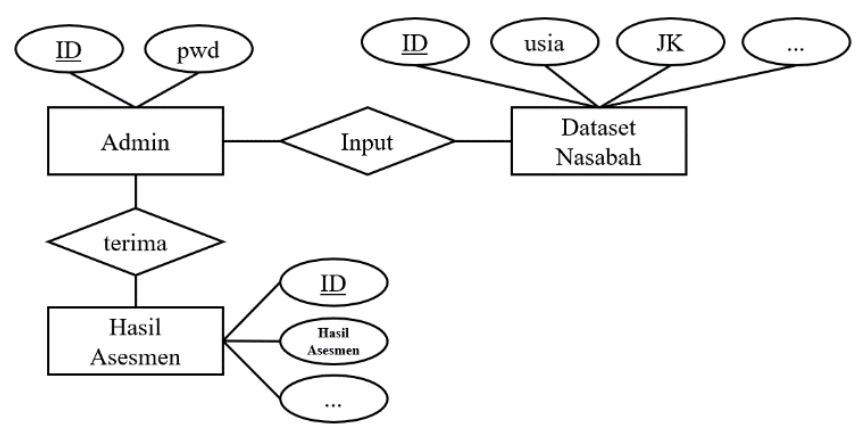

Gambar 8. Entity Relationship Diagram Aplikasi Asesmen Debitur Koperasi Mitra Sejahtera

Implementasi dari ERD tersebut menjadi perancangan basis data, yang terdiri dari tabel admin, tabel data set nasabah dan tabel hasil asesmen. Secara terperinci terdapat dalam Tabel 8, Tabel 9, dan Tabel 10,

TABLE VIII. DATA RECORD KATEGORI CLASS

\begin{tabular}{|c|l|c|c|c|}
\hline No & Field & Tipe Data & Length & Ket \\
\hline 1 & ID & Varchar & 5 & Primary Key \\
\hline 2 & Username & Varchar & 20 & - \\
\hline 3 & Password & Varchar & 10 & - \\
\hline
\end{tabular}

TABLE IX. DATA RECORD KATEGORI CLASS

\begin{tabular}{|c|l|c|c|c|}
\hline No & Field & Tipe Data & Length & Ket \\
\hline 1 & ID & Varchar & 5 & Primary Key \\
\hline 2 & Usia & Int & - & - \\
\hline 3 & JK & Varchar & 10 & - \\
\hline 4 & Jml_Pinjam & Double & - & - \\
\hline
\end{tabular}

\begin{tabular}{|c|l|c|c|c|}
\hline No & Field & Tipe Data & Length & Ket \\
\hline 5 & Pekerjaan & Varchar & 15 & - \\
\hline 6 & Penghasilan & Double & - & - \\
\hline 7 & Durasi & Int & - & - \\
\hline 8 & Status & Varchar & 18 & - \\
\hline
\end{tabular}

TABLE X. DATA RECORD KATEGORI CLASS

\begin{tabular}{|c|l|c|c|c|}
\hline No & Field & Tipe Data & Length & Ket \\
\hline 1 & ID & Varchar & 5 & Primary Key \\
\hline 2 & Tgl_Asesmen & Date & Short date & - \\
\hline 2 & Usia & Int & - & - \\
\hline 3 & JK & Varchar & 10 & - \\
\hline 4 & Jml_Pinjam & Double & - & - \\
\hline 5 & Pekerjaan & Varchar & 15 & - \\
\hline 6 & Penghasilan & Double & - & - \\
\hline 7 & Durasi & Int & - & - \\
\hline 8 & Hasil_Asesmen & Varchar & 15 & - \\
\hline
\end{tabular}

\section{E. Implementasi Sistem}

Dalam tahapan ini implementasi sistem menggunakan tool Microsoft Visual Studio 2012 dengan basis data mySQL. Terdapat beberapa form dalam aplikasi ini, salah satunya adalah form Login, dimana entitas admin mengakses sistem melalui form tersebut dengan menginputkan username dan password, seperti pada Gambar 9.

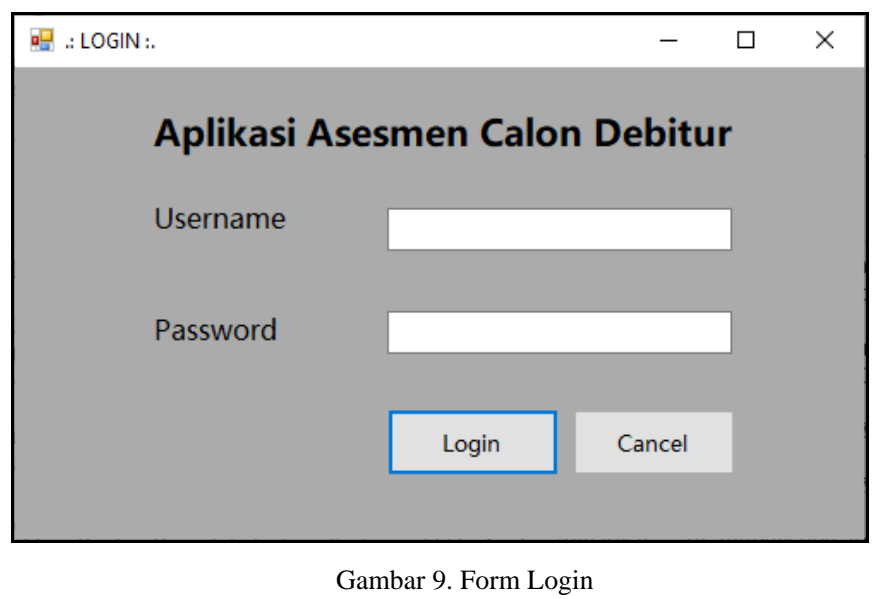

Setelah admin login dan masuk ke sistem, maka akan diarahkan ke fitur Asesmen Calon Debitur seperti pada gambar 10. Pada form ini admin mengisi kriteria calon debitur dengan menginput data Usia, Jenis Kelamin, Jumlah Pinjam, Pekerjaan, Penghasilan dan Lama Pinjaman. Setelah data terisi dan valid, selanjutnya klik tombol CEK untuk mengetahui hasil dari asesmen calon debitur. Sehingga hasil asesmen muncul berupa kotak dialog apakah Nasabah dengan ID tersebut diterima atau ditolak seperti pada gambar 11, berdasarkan data inputan yang merujuk pada data training nasabah Koperasi Mitra Sejahtera. 


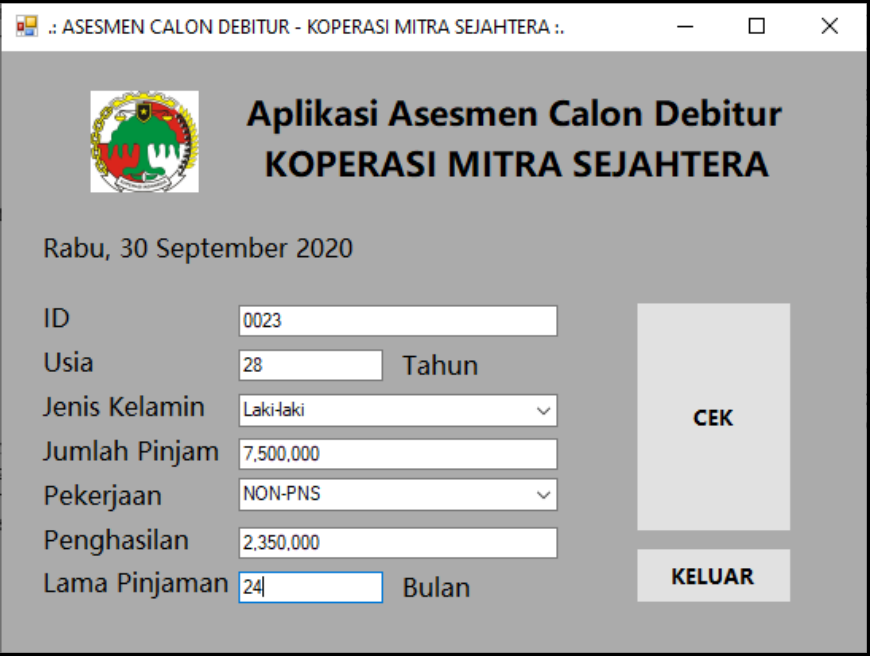

Gambar 10. Form Asesmen Calon Debitur

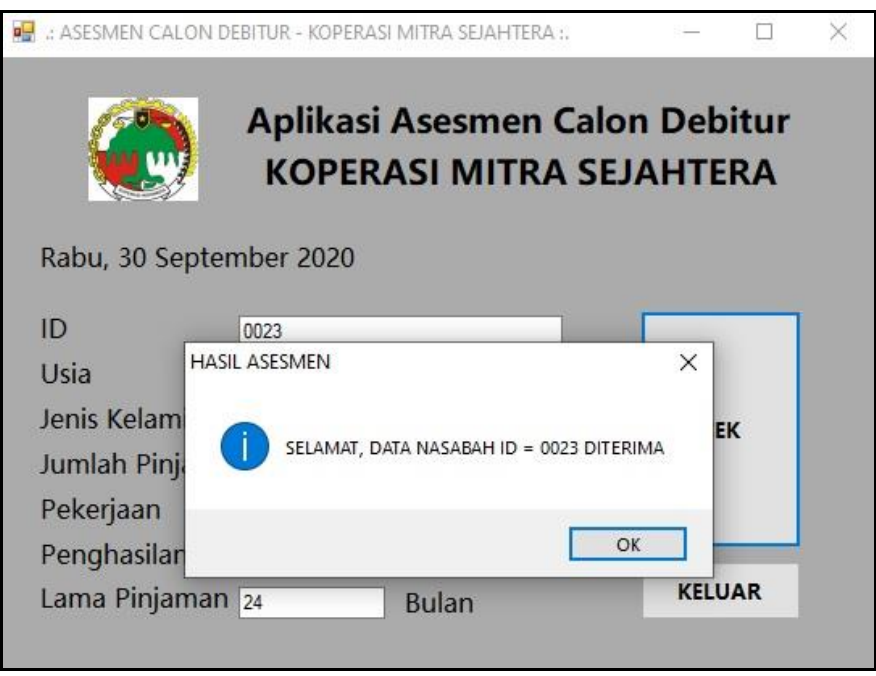

Gambar 11. Hasil Asesmen Calon Debitur

\section{F. Pengujian Program}

\section{1) Blackbox Testing}

Pengujian untuk mengukur kualitas secara fungsional dari aplikasi asesmen calon debitur Blackbox Testing, dimana terdapat 25 skenario pengujian. Tabel 11 menunjukkan hasil dari pengujian Blackbox Testing.

TABLE XI. Hasil Pengujian BLACKBoX Testing

\begin{tabular}{|c|l|l|c|}
\hline No & Skenario Pengujian & \multicolumn{1}{|c|}{ Hasil } & Ket \\
\hline 1 & $\begin{array}{l}\text { Input form login dengan } \\
\text { username dan password } \\
\text { valid }\end{array}$ & $\begin{array}{l}\text { Muncul notifikasi data } \\
\text { diterima dan masuk ke menu } \\
\text { utama }\end{array}$ & OK \\
\hline 2 & $\begin{array}{l}\text { Input form login dengan } \\
\text { username dan password } \\
\text { tidak valid }\end{array}$ & $\begin{array}{l}\text { Muncul notifikasi data } \\
\text { ditolak dan halaman tetap di } \\
\text { form login }\end{array}$ & OK \\
\hline 3 & $\begin{array}{l}\text { Klik tombol menu } \\
\text { Asesmen Calon Debitur }\end{array}$ & $\begin{array}{l}\text { Muncul form Asesmen } \\
\text { Calon Debitur }\end{array}$ & OK \\
\hline 4 & $\begin{array}{l}\text { Input form asesmen } \\
\text { calon debitur dengan } \\
\text { data yang sesuai }\end{array}$ & Muncul hasil rekomendasi & OK \\
\hline
\end{tabular}

\begin{tabular}{|c|c|c|c|}
\hline No & Skenario Pengujian & Hasil & Ket \\
\hline$\ldots$ & $\ldots$ & $\ldots$ & $\ldots$ \\
\hline 25 & $\begin{array}{l}\text { Klik cetak hasil asesmen } \\
\text { nasabah }\end{array}$ & Muncul halaman cetak & OK \\
\hline
\end{tabular}

\section{2) Accuracy Data Testing}

Pengujian ini dilakukan untuk menguji akurasi dari algoritma yang diimplementasikan dalam aplikasi asesmen calon debitur. Data yang diinputkan sebanyak 35 data testing yang diambil dari data nasabah periode Desember 2019. Data yang telah diinputkan ke aplikasi tersebut selanjutnya dibandingkan dengan data riil nasabah periode Desember 2019 untuk melihat data yang tidak sesuai dari data inputan dalam aplikasi. Berikut hasil dari perbandingan data testing dengan data riil nasabah pada tabel 12. Hasil banding yang menunjukan nilai $\mathbf{S}$ (Sesuai) artinya data testing sama dengan data riil, sedangkan nilai TS (Tidak Sesuai) menunjukkan data testing tidak sama dengan data riil.

TABLE XII. HASIL ACCURACY DATA TESTING

\begin{tabular}{|c|c|c|c|c|c|c|c|c|}
\hline No & $\mathbf{C 1}$ & $\mathbf{C 2}$ & $\mathbf{C 3}$ & $\mathbf{C 4}$ & $\mathbf{C 5}$ & $\mathbf{C 6}$ & $\begin{array}{c}\text { Hasil } \\
\text { C7 }\end{array}$ & $\begin{array}{c}\text { Hasil } \\
\text { Banding }\end{array}$ \\
\hline 1 & 25 & $\mathrm{~L}$ & 2.5 & $\mathrm{NP}$ & 5 & 6 & $\mathrm{~L}$ & $\mathrm{~S}$ \\
\hline 2 & 30 & $\mathrm{P}$ & 10 & $\mathrm{NP}$ & 3 & 12 & $\mathrm{TL}$ & $\mathrm{S}$ \\
\hline 3 & 28 & $\mathrm{~L}$ & 15 & $\mathrm{NP}$ & 3 & 12 & $\mathrm{TL}$ & $\mathrm{S}$ \\
\hline 4 & 32 & $\mathrm{~L}$ & 8.5 & $\mathrm{P}$ & 4 & 12 & $\mathrm{~L}$ & $\mathrm{~S}$ \\
\hline 5 & 37 & $\mathrm{~L}$ & 10 & $\mathrm{P}$ & 5 & 12 & $\mathrm{~L}$ & $\mathrm{~S}$ \\
\hline 6 & 55 & $\mathrm{P}$ & 5 & $\mathrm{P}$ & 5 & 12 & $\mathrm{TL}$ & $\mathrm{TS}$ \\
\hline 7 & 24 & $\mathrm{P}$ & 5 & $\mathrm{P}$ & 3 & 12 & $\mathrm{~L}$ & $\mathrm{~S}$ \\
\hline 8 & 46 & $\mathrm{~L}$ & 10 & $\mathrm{P}$ & 5 & 12 & $\mathrm{~L}$ & $\mathrm{~S}$ \\
\hline 9 & 32 & $\mathrm{~L}$ & 5 & $\mathrm{P}$ & 5 & 12 & $\mathrm{~L}$ & $\mathrm{~S}$ \\
\hline 10 & 28 & $\mathrm{~L}$ & 8.5 & $\mathrm{NP}$ & 7 & 6 & $\mathrm{~L}$ & $\mathrm{~S}$ \\
\hline 11 & 27 & $\mathrm{~L}$ & 8.5 & $\mathrm{NP}$ & 3 & 12 & $\mathrm{~L}$ & $\mathrm{TS}$ \\
\hline 12 & 32 & $\mathrm{~L}$ & 5 & $\mathrm{NP}$ & 6 & 6 & $\mathrm{~L}$ & $\mathrm{~S}$ \\
\hline 13 & 44 & $\mathrm{~L}$ & 10 & $\mathrm{P}$ & 5 & 12 & $\mathrm{~L}$ & $\mathrm{~S}$ \\
\hline$\ldots$ & $\ldots$ & $\ldots$ & $\ldots$ & $\ldots$ & $\ldots$ & $\ldots$ & $\ldots$ & $\ldots$ \\
\hline 35 & 30 & $\mathrm{P}$ & 8.5 & $\mathrm{P}$ & 4 & 12 & $\mathrm{~L}$ & $\mathrm{~S}$ \\
\hline
\end{tabular}

Dari 35 data testing yang diujikan pada sistem, dihasilkan 30 data yang memiliki nilai hasil banding $\mathbf{S}$ atau memiliki kesesuaian dengan data riil, yang artinya didapatkan bobot $86 \%$ nilai akurasi dari data testing. Sedangkan sisanya, yakni 5 data yang memiliki ketidaksesuaian antara data testing dan data riil atau tingkat eror sebesar 14\%. Seperti pada data nomor 6 menghasilkan Hasil Banding TS, hal ini karena ketidaksesuaian hasil $\mathrm{C} 7$, dimana dalam data riil dihasilkan $\mathrm{L}$ (Lunas) sedangkan pada sistem dihasilkan TL (Tidak Lunas). Sehingga disimpulkan nilai persentasi akurasi dari data testing tersebut berdasarkan perbandingan 35 data testing dengan data riil yang diambil dari data nasabah periode Desember 2019 adalah sebesar $86 \%$.

\section{KESIMPULAN}

Penerapan Naive Bayes dalam Aplikasi Asesmen Calon Debitur Koperasi Mitra Sejahtera memberikan kemudahan rekomendasi dalam mengases calon debitur yang memiliki potensi Lunas maupun Tidak Lunas melalui 7 parameter yang terdiri dari usia, jenis kelamin, jumlah pinjaman, 
pekerjaan, penghasilan, jangka waktu pengembalian dan Status Pelunasan. Dari hasil pengujian algoritma dengan menggunakan 35 data testing, didapatkan nilai akurasi sebesar $86 \%$ berdasarkan perbandingan hasil data testing dengan data riil nasabah periode Desember 2019

Adapun saran untuk pengembangan selanjutnya adalah dengan menambah jumlah data training sehingga kualitas rekomendasi yang dihasilkan lebih presisi serta mengkombinasikan metode klasifikasi lainnya dengan naive bayes

\section{REFERENCES}

[1] Mahasiswa-Ekonomi-Syariah, EKONOMI KOPERASI. Pasuruan: Fakultas Agama Islam - Universitas Yudharta Pasuruan, 2018.

[2] Kementerian-Koperasi-dan-Usaha-Kecil-dan-Mikro, "Laporan Data Koperasi Per 31 Desember 2019,” Jakarta, 2019.

[3] I. G. T. Isa and G. P. Hartawan, "Perancangan Aplikasi Koperasi Simpan Pinjam Berbasis Web (Studi Kasus Koperasi Mitra Setia)," J. Ilm. Ilmu Ekon., vol. 5, no. 10, pp. 139-151, 2017.

[4] M. Sabransyah, Y. N. Nasution, and F. D. T. Amijaya, "Aplikasi Metode Naive Bayes dalam Prediksi Risiko Penyakit Jantung," $J$. EKSPONENSIAL, vol. 8, no. 2, pp. 111-118, 2017.

[5] I. G. T. Isa, "Kansei Engineering Approach in Software Interface
Design,” J. Sci. Innovare, vol. 1, no. 01, pp. 22-26, 2018, doi: 10.33751/jsi.v1i01.680

[6] I. Listiowarni, "Implementasi Naïve Bayessian dengan Laplacian Smoothing untuk Peminatan dan Lintas Minat Siswa SMAN 5 Pamekasan," J. Sisfokom (Sistem Inf. dan Komputer), vol. 8, no. 2, p. 124, 2019, doi: 10.32736/sisfokom.v8i2.652.

[7] D. A. Kurniawan and Y. I. Kurniawan, "Aplikasi Prediksi Kelayakan Calon Anggota Kredit Menggunakan Algoritma Naïve Bayes," J. Teknol. dan Manaj. Inform., vol. 4, no. 1, 2018, doi: 10.26905/jtmi.v4i1.1831.

[8] A. P. Fadillah and B. Hardiyana, "Penerapan Naïve Bayes Classifier Untuk Pemilihan Konsentrasi Mata Kuliah," J. Teknol. dan Inf., vol. 8, no. 2, 2018, doi: 10.34010/jati.v8i2.1039.

[9] O. Maimon and L. Rokach, Data mining and knowledge discovery handbook, vol. 48, no. 10. 2011.

[10] J. Han, M. Kamber, and J. Pei, Data Mining: Concepts and Techniques. 2012.

[11] C. C. Aggarwal, "An Introduction to Data Classification," in Data Classification: Algorithms and Applications, C. C. Aggarwal, Ed. New York, USA: CRC Press, 2014, pp. 1-31.

[12] Bustami, "Penerapan Algoritma Naive Bayes untuk Mengklasifikasi Data Nasabah Asuransi," J. Inform., vol. 8, no. 1, pp. 884-898, 2014.

[13] U. R. F. Averweg, Decision-making Support Systems - Theory \& Practice. Durban, South Africa: bookboon.com, 2012

[14] I. G. T. Isa, "Aplikasi Prediksi Kelulusan Tepat Waktu dengan Algoritma Naive Bayes (Studi Kasus Program Studi Teknik Informatika UMMI)," J. Santika, vol. 7, no. 2, pp. 591-599, 2017. 